\title{
Investigating the effect of learning styles in a blended e-learning system: An extension of the technology acceptance model (TAM)
}

\author{
Ahmed Al-Azawei \\ University of Reading, UK and University of Babylon, Iraq \\ Patrick Parslow \& Karsten Lundqvist \\ University of Reading, UK
}

\begin{abstract}
This study assesses learner perceptions of a blended e-learning system (BELS) and the feasibility of accommodating educational hypermedia systems (EHSs) according to learning styles using a modified version of the technology acceptance model (TAM). Recently, Moodle has been adopted by an Iraqi university alongside face-to-face (F2F) classrooms to provide flexible learning and improve understanding. Based on TAM, individual differences and perceptions were explored in relationships between learner satisfaction and technology adoption. The model was extended to include e-learning self-efficacy, perceived satisfaction, and learning styles. Although other variables can be integrated, the proposed framework is to investigate the effect of learning styles in predicting satisfaction and BELS acceptance. A total of 210 undergraduate students voluntarily took part in the research. Data was gathered using a survey instrument and the Index of Learning Styles (ILS) Questionnaire. Partial least squares structural equation modelling (PLS-SEM) technique was used to examine the path associated between dependent and independent constructs. Unlike prior TAM literature, this research highlights the integration of perceived satisfaction and technology acceptance in accordance with psychological traits and learner beliefs. Overall, the model achieved an acceptable fit and successfully integrated intention to use (ITU) and perceived satisfaction (PS). However, psychological differences did not indicate positive impacts on learner satisfaction and e-learning adoption.
\end{abstract}

\section{Introduction}

Education has been profoundly affected by the emergence of the Internet and the integration of modern technologies. As such, online learning has been used as a form of distance learning. The core advantages of online learning are flexibility and accessibility (Wu, Tennyson, \& Hsia, 2010). This does not mean that e-learning is without its drawbacks. Many issues have to be tackled in this learning mode, for example, the absence of a learning environment, lack of e-learning experience, the difficulty of learning and understanding without direct guidance, and the weak interaction among learner-learner and learnerteacher (Bouhnik \& Marcus, 2006; Dutton, Dutton, \& Perry, 2001; Wu et al., 2010). Accordingly, physical classrooms still represent the norm irrespective of size, place, and time constraints (Liu, Chen, Sun, Wible, \& Kuo, 2010). In order to overcome those identified obstacles and benefit from online learning, blended learning has been widely adopted as a compromise between traditional and digital methods. Blended learning means "the thoughtful integration of classroom face-to-face learning experiences with online learning experiences” (Garrison \& Kanuka, 2004; p. 96). According to López-Pérez, Pérez-López and Rodríguez-Ariza (2011), blended learning can positively affect learner satisfaction and performance. Educational institutions around the world use several learning management systems (LMSs) such as Blackboard, WebCT, and Moodle alongside the more traditional classroom settings to provide flexible learning and support social constructivist approaches.

Although using LMS is becoming ubiquitous, it is still in its infancy in developing countries. This is due to the lack of financial support, low internet bandwidth, and inadequate infrastructure (Tarhini, Hassouna, \& Abbasi, 2015; Tarus, Gichoya, \& Muumbo, 2015). Moreover, lack of e-learning literacy is another reason that prevents an effective application of such technologies. In Iraq, for example, universities have recently started to apply LMS. Six public universities have registered as using Moodle (Moodle, 2016). However, many barriers still affect e-learning successful implementation in Iraq (Al-Din \& AlRadhi, 2008). As a consequence, further investigation was conducted to reveal common factors that can influence satisfaction and BELS adoption. This area of research has not been widely explored in the Middle East in comparison to West countries. We adopted TAM as a foundation because it has been extensively used to investigate 
technology adoption (Bagozzi, 2007; Shin \& Kang, 2015; Sun, Tsai, Finger, Chen, \& Yeh, 2008; Wixom \& Todd, 2005). Furthermore, the core factors of the model can predict learner satisfaction as well (Liaw, 2008; Sun et al., 2008; Weng \& Tsai, 2015). However, there is a concern regarding the appropriateness of the model across cultures (Tarhini et al., 2015; Teo, 2008; Srite \& Karahanna, 2006).

Consequently, understanding factors that may affect learner satisfaction and technology acceptance can help LMS providers in applying special strategies to attract students in adopting this learning form (Park, 2009). It is a contention of this paper that there is a gap in the research for the Middle East that empirically identifies the synergy among psychological and cognitive factors that may influence learner satisfaction and/or behavioural intention in a blended learning mode. The current research aimed at addressing this deficit. It integrated perceived satisfaction and BELS adoption in order to identify common factors that can affect both. The study also attempted to contribute to the existing evidence regarding the soundness of TAM across cultural differences. The implications of individual differences in terms of learning styles and gender on perceived satisfaction and technology acceptance were also examined. The research mainly focused on the role of learning styles in order to understand the feasibility of personalising educational hypermedia systems (EHSs) in accordance with this psychological trait. The background to this investigation was a literature of psychology that demonstrated the importance of taking into account intrinsic variables in explaining human responses to a system (Barrio-García, Arquero, \& Romero-Frías, 2015).

\section{Research model and hypotheses}

Learners have different characteristics, preferences, and needs (Felder \& Silverman, 1988; Graf, 2007). Ignoring such individual features and traits may negatively affect learner satisfaction and technology adoption. Additionally, learner perceptions towards technology have been examined in two directions: perceived satisfaction and technology acceptance (Wixom \& Todd, 2005). Prior research, however, showed that identical factors can be used to predict both (Capece \& Campisi, 2013; Weng \& Tsai, 2015).

In this research, the proposed model is based on TAM as a framework to understand the role of individual factors. Recently, TAM has attracted significant attention in e-learning research (Ahuja \& Thatcher, 2005; Liaw, 2008; Shin \& Kang, 2015; Sun et al., 2008; Teng, 2015; Teo, 2008). Venkatesh \& Davis (1996), on the other hand, illustrated that the model can be extended in order to enhance its effectiveness. Legris, Ingham and Collerette (2003) critically reviewed TAM, stating that other variables should be included to understand those factors that affect technology adoption. This conclusion was also confirmed by Edmunds, Thorpe and Conole (2012) to indicate that the two factors of TAM (usefulness and ease of use) may not identify all significant components in predicting technology acceptance. Furthermore, one of the debates on TAM is that it did not account for user and cultural differences or their influence on technology adoption (Bagozzi 2007; Benbasat \& Barki 2007; Straub \& Burton-Jones 2007).

Accordingly, this study attempts to overcome such limitations by considering learning styles and gender. The reason behind their choice is that both factors have been regarded as a function of individual and cultural differences (Cagiltay \& Bichelmeyer, 2000; Chang et al., 2011; Dunn et al. 1990; Gefen \& Straub, 1997; Oxford \& Anderson, 1995).

\section{Technology acceptance model (TAM)}

Based on the theory of reasoned action (TRA) (Ajzen \& Fishbein, 1980) and the theory of planned behaviour (TPB) (Ajzen, 1985, 1991), TAM was proposed by Davis (1986). This model was significant for TRA which suggests that attitude towards use (ATU) is a mediator between user beliefs (perceived usefulness) and behavioural intention. For TAM, however, the expectation of enhancement in job performance was described as a direct predictor of intention to use (ITU). The theoretical justification for this change is that users may not prefer to use technology, but may still continue to use it because of their positive perceptions regarding its impacts on job performance (Davis, Bagozzi, \& Warshaw, 1989). This modification was regarded as the most important alteration to the TRA (Taylor \& Todd, 1995). Although the model was extended to propose technology acceptance model 2 (TAM2) (Venkatesh \& Davis, 2000), unified theory of acceptance and use of technology (UTAUT) (Venkatesh, Morris, Davis, \& Davis, 2003), and technology acceptance model 3 (TAM3) (Venkatesh \& Bala, 2008), TAM has been considered one of the most influential theories in information technology (IT) (Benbasat \& Barki, 2007; Lee, Kozar, \& Larsen, 2003), and to predict e-learning acceptance (Šumak, Heričko, \& Pušnik, 2011). 
Davis (1986) shows that perceived usefulness (PU) is directly affected by perceived ease of use (PEOU) and both, in turn, affect user attitude. Perceived usefulness comes from the user's beliefs that a particular technology can help him/her improve job performance, whereas perceived ease of use comes from the beliefs of users that technology is relativity free from mental effort (Davis, 1986). ATU explains users' positive or negative evaluation in accomplishing certain behaviours (Ajzen \& Fishbein, 1980). Furthermore, TAM assumes a direct effect of PU and ATU on ITU. However, recent research established that ATU is a weak mediator between PEOU, PU, and ITU (Szajna, 1996; Venkatesh \& Davis, 2000). This factor, therefore, was excluded from the analysis of the present research. The main hypotheses of TAM are:

H1: PEOU positively affects PU
H2: PEOU positively affects ITU
H3: PU positively affects ITU

\section{E-learning self-efficacy}

Another integrated cognitive factor is blended e-learning system self-efficacy (BELSSE). Tarhini, Hone and Liu (2014; p. 167-168) defined BELSSE as "a student's self-confidence in his or her ability to perform certain learning tasks using the e-learning system”. Users with low perception regarding their abilities to use a technology may not persist in tackling obstacles that face them. It was stated that this factor is a determinant of PU and PEOU (Hong, Thong, James, Wong, \& Tam, 2001; Ong \& Lai, 2006; Venkatesh \& Davis, 1996). Building on these positive findings, it was incorporated in our proposed model.

H4: BELSSE positively affects PEOU

H5: BELSSE positively affects PU

\section{Learning styles}

According to Barrio-García et al. (2015), literature has shown the significant role of psychological traits such as learning styles in explaining and understanding user reactions to systems. Huang (2015) also indicates that the exploration of learner intention to use learning technology from a learning styles perspective remains scant. Coffield, Moseley, Hall and Ecclestone (2004) found that literature includes up to 71 learning style models. Some learning style theories, however, have come to dominate in the empirical research such as Dunn and Dunn's (1974) model, Kolb’s (1981) model, the VARK model (Fleming \& Mills, 1992), and Felder and Silverman's (1988) model. For this research, we adopted the Felder and Silverman learning styles model (FSLSM) because it has been regarded as significant in educational research, and technology enhanced learning (TEL) (Akbulut \& Cardak, 2012; Cha, Kim, Park, \& Yoon, 2006; Graf, 2007). The four dichotomies of this model are briefly described as follows:

- $\quad$ Processing (active/reflective): Active learners prefer studying in groups and immediately doing learning tasks, while reflective learners use analytical approaches and prefer to study alone.

- $\quad$ Perception (sensing/intuitive): Sensing learners prefer facts and following the tutors approach in problem solving, whereas intuitive learners tend to prefer complex content and apply their own innovation approaches.

- Input (visual/verbal): This dimension refers to the preferred way of receiving information. Visual learners prefer video, demonstrations, pictures, and graphs. Verbal learners, in contrast, prefer written materials and listen to others explanation.

- Understanding (sequential/global): Sequential refers to learners who focus on details and study step by step, whereas global learners connect all concepts together to understand the bigger picture before looking at details.

Some psychologists state that learning styles are one of the most important individual differences that affect learner performance and satisfaction (Dunn \& Dunn, 1974; Felder \& Silverman, 1988; Kolb \& Kolb, 2005). The key concept underlies the learning styles theory is that learning and teaching styles have to be matched in order to improve the learning experience. This was the so-called meshing hypothesis (Pashler, McDaniel, Rohrer, \& Bjork, 2009). The theory assumes that learning styles can motivate students, enhancing achievement, and/or satisfaction. Hence, many studies have adapted EHSs in accordance with those learning styles (Akbulut \& Cardak, 2012; Brown, 2007; Graf, 2007; Popescu, 2010). 
Several issues, however, still surround the theory of learning styles. There is the less-than-obvious definition of learning styles. Felder (1996; p. 18) defines learning styles as "characteristic strengths and preferences in the ways they take in and process information". This overlaps with other terminologies such as cognitive styles and learning approaches. Other critiques exist regarding malleability, lack of reliable measurements, which genes are associated with learning styles, and the absence of convincing evidence to support their pedagogical implications (Coffield et al., 2004; Mayer, 2011; Peterson, Rayner, \& Armstrong, 2009).

In this research, the blended e-learning environment was not adapted to individual styles. A one-size-fitsall teaching approach was used. Hence, learning styles of some learners were certainly mismatched. Even if learning styles are ignored, our methodology allows us to reveal the perspectives of every learner and, thus, examine implications of learning styles. Although the relationship between learning styles theory and e-learning technology has been established (Huang, 2015; Li, 2015), its association with PU, PS, and ITU has not been investigated in previous TAM work. However, the learning styles hypothesis assumes such link. Furthermore, learning styles as an influential factor on PS is evidently stated (Felder \& Brent, 2005). Accordingly, we assumed that learning style is a predictor factor of PU, PS, and ITU.

H6: Learning styles positively affect PU

H7: Learning styles positively affect PS

H8: Learning styles positively affect ITU

\section{Perceived satisfaction}

Wu et al. (2010; p. 157) define learner satisfaction in BELS as "the sum of student's behavioural beliefs and attitudes that result from aggregating all the benefits that a student receives from using BELS". Assessing learner satisfaction in blended learning is very important because this can provide a sophisticated view about the effectiveness of blended learning in higher education (Garrison \& Kanuka, 2004). According to Bolliger and Wasilik (2009), there is a link between learner satisfaction and performance. This means that educational institutions should do their best to meet learner needs. The high expectation that a particular learning technology that utilises less effort and can enhance learning outcomes may lead to promoting learner satisfaction.

Studies pointed out that PU and PEOU influence learner satisfaction (Liaw, 2008; Sun et al., 2008; Weng \& Tsai, 2015). The correlation between these variables is based on the notion that users will not be satisfied if they believe that a particular system will not help to enhance their performance or it is difficult to use. Hence, we assumed that both factors positively impact perceived satisfaction (PS).

H9: PEOU positively affects PS

H10: PU positively affects PS

Figure 1 depicts the proposed model. 


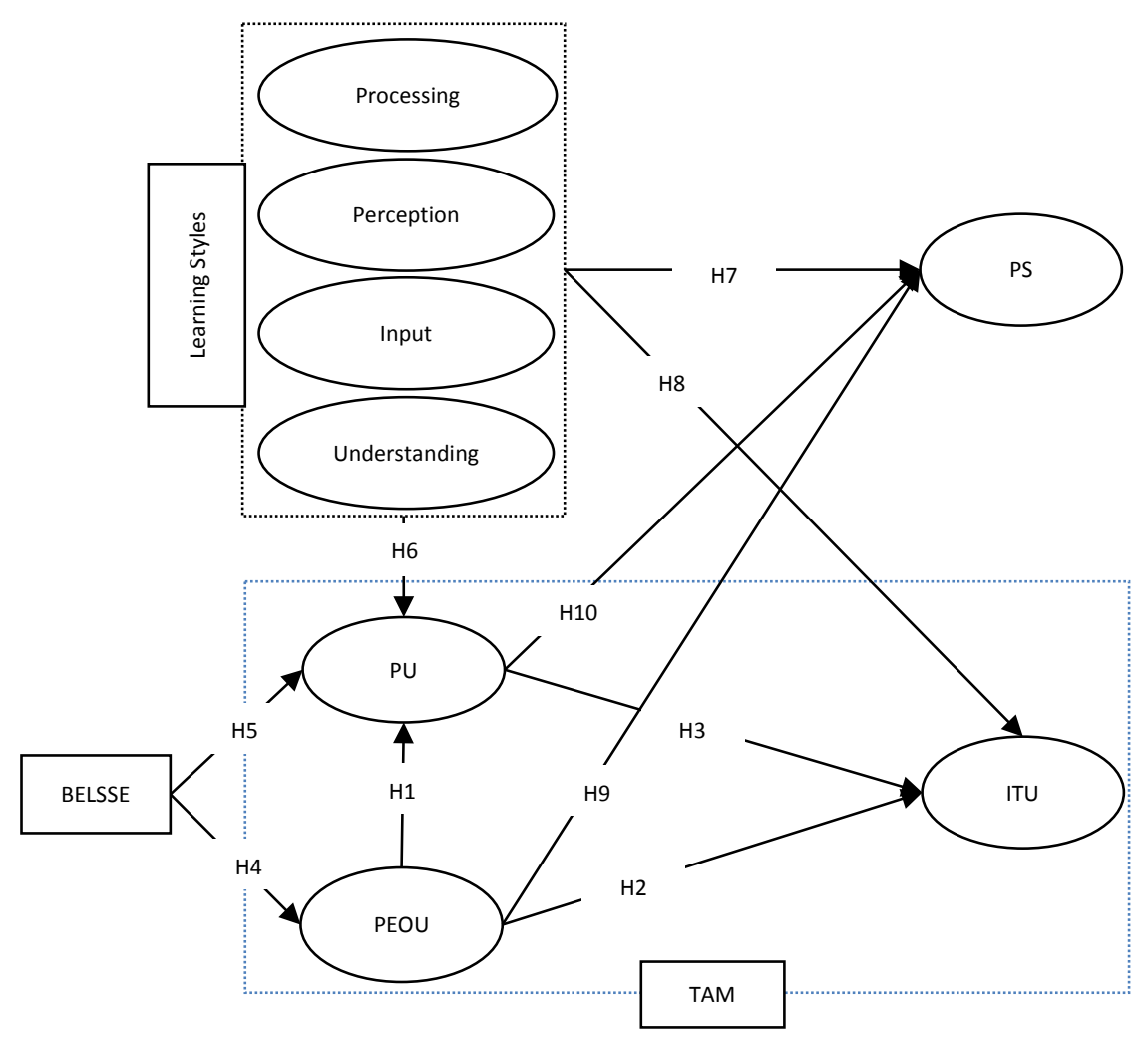

Figure 1. Research framework

\section{Research methodology}

This study was carried out at the University of Babylon during the academic year of 2014-2015. It is one of the leading universities in the adoption of e-learning in Iraq. The aim was to investigate factors that affect technology adoption and perceived satisfaction of BELS as well as highlighting the effectiveness of treating learners individually according to their learning styles and gender differences. A mixed-methods survey research design was employed. The aim of this approach is to examine the correlation among different factors, which can then be generalised (Dash, 2005). Survey research design was appropriate for this study because it aims to reveal the causal relationship between the identified constructs. One of the limitations of survey design in a positivist paradigm, however, is that the objectivity of research inquiry where human behaviours are considered to be passive, identified, and controlled by the external environment (Dash, 2005). In order to overcome such problems, qualitative data was also gathered to gain further understanding of learner perspectives. Qualitative data was grouped using a thematic approach (Runeson \& Höst, 2009). In this context, however, access to the whole population is very difficult, even impossible. Accordingly, a non-probabilistic sampling approach was adopted to select the research sample (Cohen, Manion, \& Keith, 2007).

\section{Context}

At the College of Information Technology, Moodle has been used alongside the physical classrooms since the end of 2013. Formally, courses were taught via blended learning (F2F and LMS) where all students were registered in the system. All learning materials were uploaded to the LMS as pdf or PowerPoint files in order to facilitate information retrieval. Moreover, theoretical exams were taken online to avoid the paper-based approach. Students were also encouraged to use communication tools such as the forum and wiki to support their educational interaction with other colleagues and instructors. 


\section{Participants}

This study targeted undergraduate computer science students who attended several courses via BELS. At the second semester they were asked, in classes and via the announcement page of Moodle, to fill in the online surveys. The research instruments were separately distributed in order to avoid respondent fatigue. According to Dillman (2007), the long questionnaire could lead to a low response. From the whole requested population, approximately $45.25 \%(N=210)$ students voluntarily completed the research instrument (see Appendix A). Out of the total, 169 participants filled out the ILS questionnaire. For the purposes of this research however, the total number of cases (210) was used. Table 1 illustrates demographic information of the sample.

Table 1

Demographic Information $(N=210)$

\begin{tabular}{lcc}
\hline Factor & $\mathbf{N}$ & $\mathbf{\%}$ \\
\hline Gender & 88 & 41.9 \\
Male & 122 & 58.1 \\
Female & & \\
Age Group & 124 & 59.0 \\
$18-20$ & 82 & 39.0 \\
$21-23$ & 2 & 1.0 \\
$24-26$ & 1 & 0.5 \\
$27-29$ & 1 & 0.5 \\
$30+$ & & \\
Study year & 68 & 32.4 \\
Freshman & 77 & 36.7 \\
Sophomore & 42 & 20.0 \\
Junior & 23 & 11.0 \\
Senior & &
\end{tabular}

\section{Data collection}

Prior to data collection, ethics approval was sought, and obtained, using the procedures laid down by the ethics committee at the University of Reading. Two questionnaires were administrated online via the announcement page of Moodle. It is noteworthy that both were translated into the Arabic language because the majority of undergraduate students in Iraq have only a moderate English ability. As such, using the English versions could have been unduly time consuming or may have led to lower participation. The translation was approved by two Arabic PhD students who are studying in the UK. They were chosen because of their high English proficiency. All received questionnaires were valid because all items were identified as required to avoid receiving incomplete answers.

The ILS

This instrument was proposed by Felder and Soloman (n.d.) to infer learning styles according to FSLSM. It is freely available and learners can self-assess their learning preferences. They have to choose either (a) or (b) of 44 questions where 11 indicators are constructed to diagnose each dimension. This questionnaire is widely explained in the literature (Al-Azawei \& Lundqvist, 2014; Graf, 2007). Van Zwanenberg, Wilkinson and Anderson (2000) suggested assigning 1 to all (a) items and 0 to all (b) items in order to facilitate the use of the ILS scores in the standard statistic. For every dimension, this approach derives values between 0 and 11 (0, 1: strong tendency for the left side; 2, 3: moderate tendency for the left side; 4, 5: mild tendency for the left side; 6, 7: mild tendency for the right side; 8, 9: moderate tendency for the right side; and 10,11: strong tendency for the right side). With regard to the reliability and validity of the instrument, literature supported both (Cook \& Smith, 2006; Felder \& Spurlin, 2005; Zywno, 2003). The 44 questions were followed by an open-ended question highlighting pros and cons of BELS from the learners' perspective.

\section{A survey instrument}

A general explanation was provided about the purpose of the study, declaring that all data would be manipulated confidentially. This questionnaire included three parts. The first part identified some demographic information, while part 2 comprised 17 indicators to infer the five factors (intention to use, 
perceived usefulness, perceived ease of use, e-learning self-efficacy, and perceived satisfaction), but two items were deleted after conducting factor analysis due to their weak loading. A 7-point Likert scale was used which ranging from 1 for (strongly disagree) to 7 for (strongly agree). Part 3 represented an openended question to collect qualitative data. Students were asked to add any comments that related to the use of BELS. Although all items were adapted from previously validated questionnaires (Chiu, Hsu, Sun, Lin, \& Sun, 2005; Venkatesh \& Davis, 2000; Wu et al, 2010), we initially tested the first 30 responses to prove the constructs validity. All factors achieved an acceptable and good level of reliability, which led to keeping all items without any change (Appendix A).

\section{Analysis techniques}

Both Statistical Package for Social Science (SPSS) software version 22 and SmartPLS software package version 3.0 for Windows 7 were used. Both descriptive and inferential statistics were applied to compute mean, standard deviation, frequency, Pearson's correlation coefficient, Cronbach's coefficient alpha, independent samples $t$-test, one-way ANOVA, and factor analysis in the former, whereas partial least squares (PLS) model, convergent validity, and discriminant validity were computed in the latter. The significant alpha of 0.05 was adopted.

\section{Results}

The theoretical model was tested using PLS-SEM path modelling (Chin, 1998). SEM has many advantages in comparison to traditional statistics such as regression. Reasons for its choice was that firstly, it has the ability to examine the association between a series of factors (independent and dependent variables) (Tarhini et al., 2015), more specifically for this study, when a dependent variable becomes an independent such as PU and PEOU. Secondly, Chin (1998) states that the SEM is an adequate method for predictive purposes and development of theory. Moreover, Tobias (1995) indicates the appropriateness and utility of this technique in explaining and predicting the behaviour of responses (variables) from the identified factors (independent constructs). Finally, this method has been widely used in prior literature to examine the path associated between different variables in a research model (Barrio-García et al., 2015; Shin \& Kang, 2015; Tarhini et al., 2015).

\section{Scores of the ILS}

Table 2 draws the preferences of the participants based on the ILS scores. Students were fairly well balanced on the understanding dimension (sequential/global). The mean of the sequential preference is 5.871 and the mean of the global value is 5.129 which was computed as a complement of 11 . For other dimensions, students ranged from mild to moderate preferences toward active/reflective, sensing/intuitive, and visual/verbal. The most reoccurring styles of participants were active $(N=120,71 \%)$, sensing $(N=143$, $84.6 \%)$, visual $(N=140,82.8 \%)$, and sequential $(N=88,52.1 \%)$ which support the assumption of Felder and Silverman (1988) regarding the preferences of engineering students. Figure 2 depicts the box plot of the four scales.

Table 2

Descriptive statistics for the learning style dimensions

\begin{tabular}{lcccccc}
\hline Learning Style Scales & $\boldsymbol{N}$ & Range & Min & Max & Mean & SD \\
\hline Processing (active/reflective) & 169 & 10.00 & 1.00 & 11.00 & 6.432 & 1.907 \\
Perception (sensing/intuitive) & 169 & 10.00 & 1.00 & 11.00 & 7.272 & 1.963 \\
Input (visual/verbal) & 169 & 10.00 & 1.00 & 11.00 & 7.574 & 2.213 \\
Understanding (sequential/global) & 169 & 11.00 & 0 & 11.00 & 5.781 & 2.114 \\
\hline
\end{tabular}




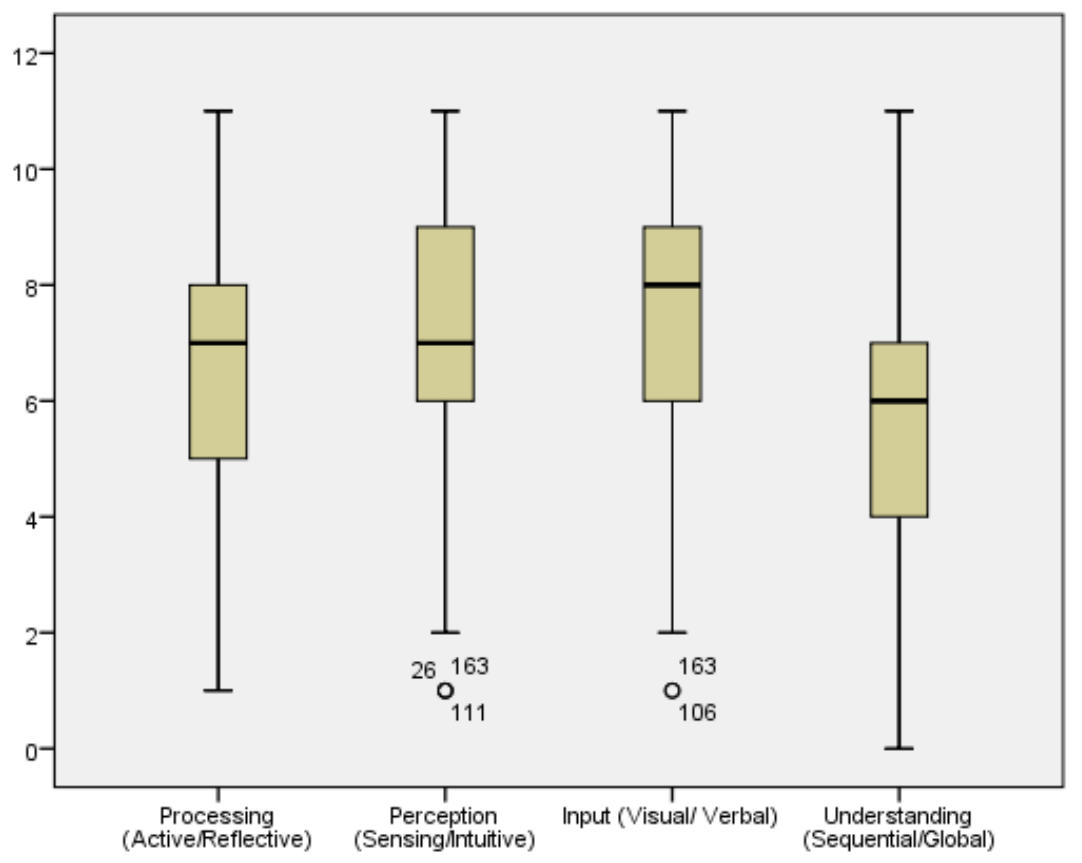

Figure 2. Box plot of the four learning style scales

\section{Descriptive statistics}

Table 3 depicts the descriptive statistics. Mean scores of all factors are higher than the midpoint of 3.5 and ranged from 4.90 to 5.29 , whereas standard deviation ranged from 1.19 to 1.32 . This indicates that there was a moderate spread of values around the mean. Moreover, skewness and kurtosis indicated that data was approximately normally distributed. Further, tolerance and VIF demonstrated that the multi-collinearity assumption was not violated.

Table 3

Descriptive statistics of the model constructs

\begin{tabular}{lccccccc}
\hline Factor & Item & $\boldsymbol{M}$ & $\boldsymbol{S D}$ & Skewness & Kurtosis & Tolerance & VIF \\
\hline ITU & 2 & 5.29 & 1.287 & -1.429 & 1.801 & 0.516 & 1.938 \\
PU & 3 & 4.90 & 1.32 & -0.911 & 0.378 & 0.523 & 1.913 \\
PEOU & 4 & 5.135 & 1.192 & -1.082 & 1.039 & 0.533 & 1.875 \\
BELSSE & 3 & 5.03 & 1.294 & -0.837 & 0.237 & 0.639 & 1.565 \\
PS & 3 & 5.076 & 1.319 & -1.204 & 1.124 & 0.497 & 2.010 \\
\hline
\end{tabular}

Pearson correlation was applied to measure the relationship among learning styles, gender differences, and the model factors. Table 4 shows that the constructs are significantly correlated and no correlation was above 0.8. The highest correlation was between PU and PS $(r=0.662)$. Neither gender nor learning styles significantly correlated with all factors, except for processing dimension where it showed a significant relationship with most constructs. However, this dimension was not supported in the PLS equation due to the stronger effect of other entered constructs to the equation. In Table 5, ITU and PS were investigated in accordance with gender differences and learning styles. None of the groups indicated a significant difference, the only exception was processing dimension where active learners were more likely to adopt BELS and more satisfied in such learning environments. Table 6 depicts the findings of the one-way ANOVA test that measured ITU and PS according to participants' year of study. It is shown that there is a significant difference between groups. Figure 3 illustrates the box plot of the model factors. 

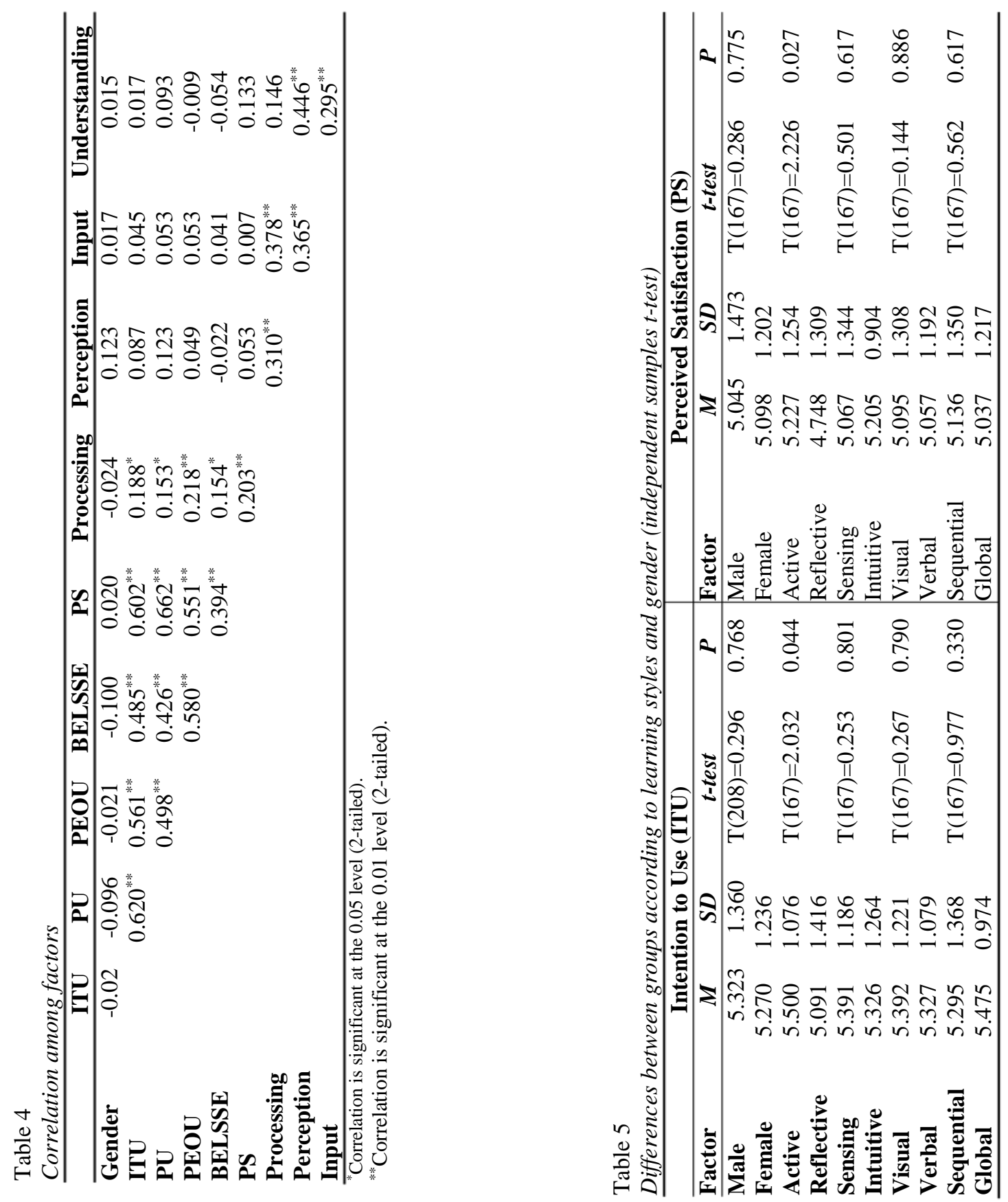

Table 6

Differences between groups according to year of study (one-way ANOVA)

\begin{tabular}{lccccc}
\hline & \multicolumn{2}{c}{ Intention to Use (ITU) } & \multicolumn{2}{c}{ Perceived Satisfaction (PS) } \\
\hline Study Year & $\boldsymbol{N}$ & $\boldsymbol{M}$ & $\boldsymbol{S D}$ & $\boldsymbol{M}$ & $\boldsymbol{S D}$ \\
\hline Freshmen & 68 & 5.397 & 1.128 & 5.269 & 1.073 \\
Sophomore & 77 & 5.383 & 1.240 & 5.168 & 1.351 \\
Junior & 42 & 4.797 & 1.565 & 4.269 & 1.548 \\
Senior & 23 & 5.587 & 1.164 & 5.666 & 0.717 \\
Total & 210 & 5.292 & 1.287 & 5.076 & 1.319 \\
\hline ANOVA & & $F(3,206)=2.819, P=0.04$ & $F(3,206)=8.127, P<0.001$ \\
\hline
\end{tabular}




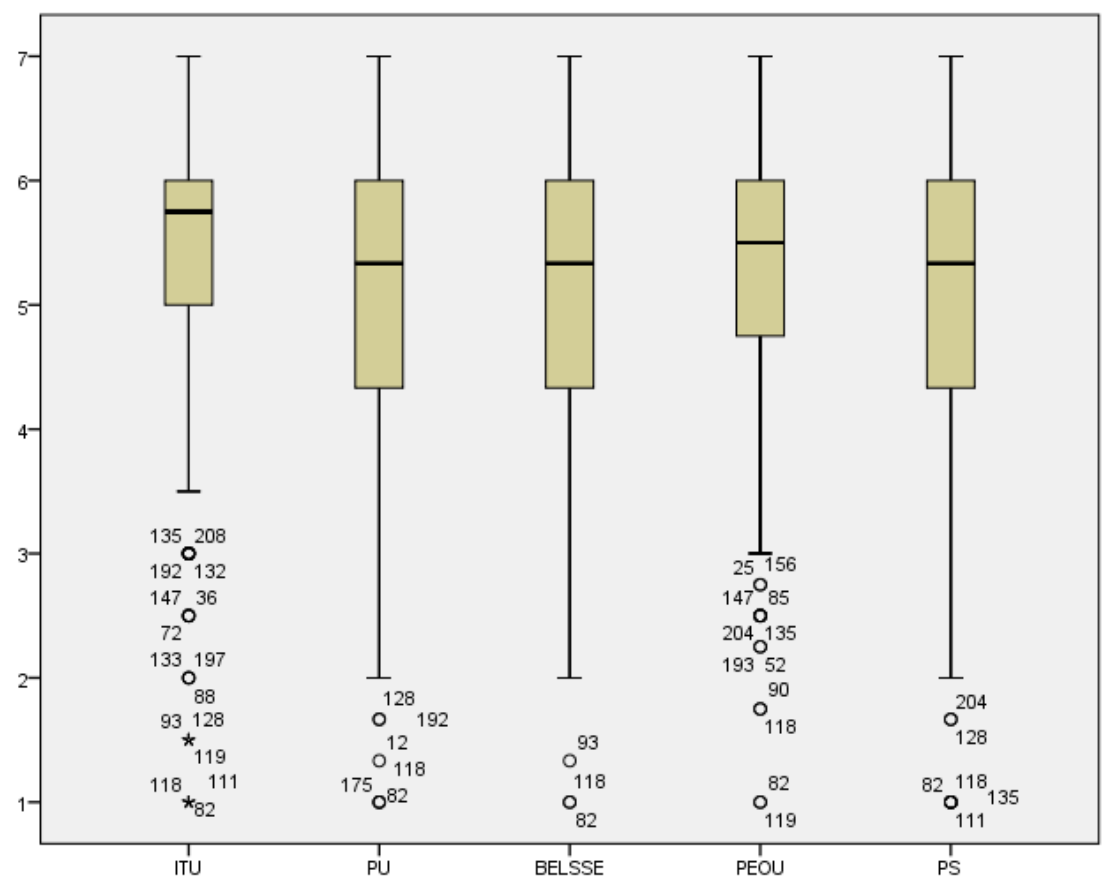

Figure 3. Box plot of the model factors

\section{Instrument properties}

Pallant (2013) recommended that Cronbach's coefficient alpha above 0.7 represents an acceptable level of reliability. Generally, the instrument had strong psychometric properties. It achieved excellent internal consistency reliability (0.910) and all constructs exhibited acceptable and high reliability where alphas ranged from 0.77 to 0.87 . For further measurement, a factor analysis was conducted. The data set was appropriate to carry out this test because all recommended criteria by Pallant (2013) were met. First, the number of observations is more than 150. Second, the correlation matrix revealed higher than 0.3 correlations among items. Third, the values of Kaiser-Meyer-Olkin (KMO) index and Bartlett's sphericity test as data factorability measurements are 0.890 and $p<0.001$ for both tests respectively. Appendix B depicts the findings of the principle component analysis (PCA) with Varimax rotation method. The presence of five factors model explains $73.98 \%$ of the variance.

Convergent and discriminant validity were also examined. Convergent validity means "the extent to which indicators of a factor that are theoretically related should correlate highly” (Park, 2009; p. 155). David (2012) state that correlation between constructs equal or larger than 0.85 means poor discriminant validity. Furthermore, to establish convergent validity, the values of average variance extracted (AVE) and composite reliability (CR) should exceed the acceptable level of 0.5 and 0.7 of both measurements respectively (Hair, Black, Babin, Anderson, \& Tatham, 2006), whereas the discriminant validity can be supported when the variance shared between any variable and other variables is smaller than the variance that a variable shares with its own constructs (Fornell \& Larcker, 1981). Table 7 illustrates that convergent and discriminant validities of the instrument were advocated.

Table 7

Convergent and discriminant validity

\begin{tabular}{lcccccccc}
\hline Latent factor & $\boldsymbol{A} \boldsymbol{V} \boldsymbol{E}$ & $\boldsymbol{C R}$ & Cronbach's $\boldsymbol{\alpha}$ & \multicolumn{5}{c}{ Discriminant validity } \\
\cline { 5 - 9 } & $\mathbf{( > 0 . 5 )}$ & $\mathbf{( > 0 . 7 )}$ & & $\mathbf{B E L S S E}$ & ITU & PEOU & PS & PU \\
\hline BELSSE & 0.70 & 0.875 & 0.786 & 0.836 & & & & \\
ITU & 0.846 & 0.916 & 0.817 & 0.487 & 0.920 & & & \\
PEOU & 0.593 & 0.852 & 0.771 & 0.59 & 0.59 & 0.770 & & \\
PS & 0.793 & 0.920 & 0.870 & 0.402 & 0.607 & 0.594 & 0.891 & \\
PU & 0.701 & 0.875 & 0.787 & 0.421 & 0.631 & 0.525 & 0.670 & 0.837 \\
\hline
\end{tabular}




\section{Investigating original factors of TAM}

In order to understand the actual predictive ability of learning style dimensions on PS and ITU, the model was firstly investigated in accordance with the two original constructs of TAM (PU and PEOU). The results of PLS are shown in Table 8. Generally, the model achieved an acceptable fit and significance. It explains for $49.1 \%$ and $53.1 \%$ of ITU and PS respectively. Additionally, PEOU was a predictive factor of PU $\left(\beta_{P E O U \rightarrow P U}=0.424, p<0.001\right)$. In order to predict ITU, PU $\left(\beta_{P U \rightarrow I T U}=0.443, p<0.001\right)$ and PEOU $\left(\beta_{P E O U \rightarrow I T U}=0.358, p<0.001\right)$ had a significant direct influence on this factor. Similarly, both PU $\left(\beta_{P U \rightarrow P S}\right.$ $=0.494, p<0.001)$ and PEOU $\left(\beta_{P E O U} \rightarrow P S=0.335, p<0.001\right)$ were predictors of PS. However, PU was the best predictor. The analysis also supports the influence of BELSSE on PEOU $\left(\beta_{B E L S S E} \rightarrow\right.$ PEOU $=0.590, p<$ $0.001)$ and PU $\left(\beta_{B E L S S E} \rightarrow P U=0.171, p=0.02\right)$.

Table 8

The original TAM hypotheses

\begin{tabular}{lccclccc}
\hline \multicolumn{3}{c}{ Perceived Satisfaction (PS) } & \multicolumn{4}{c}{ Intention to Use (ITU) } \\
\hline Path & $\boldsymbol{R}^{\mathbf{2}}$ & $\boldsymbol{\beta}$ & $\boldsymbol{p}$ & Path & $\boldsymbol{R}^{\mathbf{2}}$ & $\boldsymbol{\beta}$ & $\boldsymbol{p}$ \\
& 0.531 & & & & 0.491 & & \\
PU $\rightarrow$ PS & & 0.494 & $<0.001$ & PU $\rightarrow$ ITU & & 0.443 & $<0.001$ \\
PEOU $\rightarrow$ PS & & 0.335 & $<0.001$ & PEOU $\rightarrow$ ITU & 0.358 & $<0.001$ \\
PEOU $\rightarrow$ PU & 0.424 & $<0.001$ & PEOU $\rightarrow$ PU & 0.531 & $<0.001$ \\
BELSSE $\rightarrow$ PEOU & & 0.590 & $<0.001$ & BELSSE $\rightarrow$ & 0.590 & $<0.001$ \\
& & & PEOU & & \\
BELSSE $\rightarrow$ PU & & 0.171 & 0.02 & BELSSE $\rightarrow$ PU & 0.171 & 0.02 \\
\hline
\end{tabular}

Investigating hypotheses of the proposed model

Table 9 illustrates the findings for the path associated with the proposed constructs, whereas Figure 4 depicts the model after conducting PLS. Seven out of ten hypotheses were confirmed. Based on this analysis, none of the learning style dimensions appeared to predict PU, PS and ITU, except for the understanding dimension which only had a direct significant effect on PS. In addition, all hypotheses of TAM were advocated. The PLS resulted that PEOU $\left(\beta_{P E O U \rightarrow P S}=0.331, p<0.001\right)$, PU $\left(\beta_{P U \rightarrow P S}=0.486, p\right.$ $<0.001)$, and understanding dimension $\left(\beta_{\text {Understanding } \rightarrow P S}=0.112, p=0.050\right.$ ) were predictors of PS $\left(R^{2}=0.545\right)$. Moreover, BELSSE showed a direct significant influence on PEOU $\left(\beta_{B E L S S E} \rightarrow P E O U=0.590, p<\right.$ $0.001)$ and PU $\left(\beta_{B E L S S E} \rightarrow P U=0.181, p=0.012\right)$. In order to identify predictors of ITU, the PLS equation revealed that two factors: $\mathrm{PU}\left(\beta_{P U \rightarrow I T U}=0.443, p<0.001\right)$, and PEOU $\left(\beta_{P E O U \rightarrow I T U}=0.352, p<0.001\right)$ were determinant of ITU $\left(R^{2}=0.492\right)$.

Table 9

Findings of the research hypotheses

\begin{tabular}{|c|c|c|c|c|c|c|c|c|}
\hline $\begin{array}{l}\text { Dependent } \\
\text { Factor }\end{array}$ & $\begin{array}{l}\text { Independent } \\
\text { Factor }\end{array}$ & $\begin{array}{l}\text { Direct } \\
\text { Effect }\end{array}$ & t-value & $\boldsymbol{P}$ & $\begin{array}{c}\text { Indirect } \\
\text { Effect }\end{array}$ & t-value & $\begin{array}{l}\text { Total } \\
\text { Effect }\end{array}$ & Finding \\
\hline \multirow{7}{*}{$\begin{array}{c}\text { ITU } \\
\left(R^{2}=0.492\right)\end{array}$} & $\underline{\mathrm{PU}}$ & 0.443 & 6.765 & $<0.001$ & & & & Supported \\
\hline & PEOU & 0.352 & 5.217 & $<0.001$ & 0.148 & 4.4550 & 0.536 & Supported \\
\hline & Learning Styles & & & & & & & \multirow{5}{*}{ Rejected } \\
\hline & Processing & 0.027 & 0.511 & 0.610 & 0.005 & 0.189 & 0.032 & \\
\hline & Perception & 0.021 & 0.361 & 0.718 & 0.034 & 1.036 & 0.055 & \\
\hline & Input & -0.006 & 0.121 & 0.904 & -0.020 & 0.569 & -0.026 & \\
\hline & Understanding & -0.036 & 0.570 & 0.569 & 0.032 & 0.867 & -0.003 & \\
\hline \multirow{9}{*}{$\begin{array}{c}\text { PS } \\
\left(R^{2}=0.545\right)\end{array}$} & PU & 0.486 & 7.713 & $<0.001$ & & & 0.486 & Supported \\
\hline & PEOU & 0.331 & 4.821 & $<0.001$ & 0.202 & 4.320 & 0.533 & Supported \\
\hline & Learning Styles & & & & & & & \multirow{5}{*}{$\begin{array}{l}\text { Partially } \\
\text { Rejected }\end{array}$} \\
\hline & Processing & 0.073 & 1.342 & 0.180 & & & 0.073 & \\
\hline & Perception & -0.065 & 1.154 & 0.249 & 0.037 & 1.075 & -0.028 & \\
\hline & Input & -0.068 & 1.395 & 0.16 & -0.022 & 0.573 & -0.090 & \\
\hline & Understanding & 0.112 & 1.958 & 0.050 & 0.035 & 0.843 & 0.147 & \\
\hline & BELSSE & 0.181 & 2.503 & 0.012 & 0.245 & 4.740 & 0.426 & Supported \\
\hline & $\overline{\mathrm{PEOU}}$ & 0.415 & 5.655 & $<0.001$ & & & & Supported \\
\hline
\end{tabular}




\begin{tabular}{clccccc}
\hline PU & Learning Styles & & & & & \\
$\left.\mathbf{R}^{2}=\mathbf{0 . 3 0 9}\right)$ & Processing & 0.012 & 0.192 & 0.848 & 0.012 & \\
& Perception & 0.076 & 1.351 & 0.16 & 0.076 & Rejected \\
& Input & -0.045 & 0.587 & 0.557 & -0.045 & \\
& Understanding & 0.073 & 0.891 & 0.373 & 0.073 & \\
\hline PEOU & BELSSE & 0.590 & 10.228 & $<0.001$ & 0.590 & Supported \\
$\left(\mathbf{R}^{2}=\mathbf{0 . 3 4 8 )}\right.$ & & & & & \\
\hline
\end{tabular}

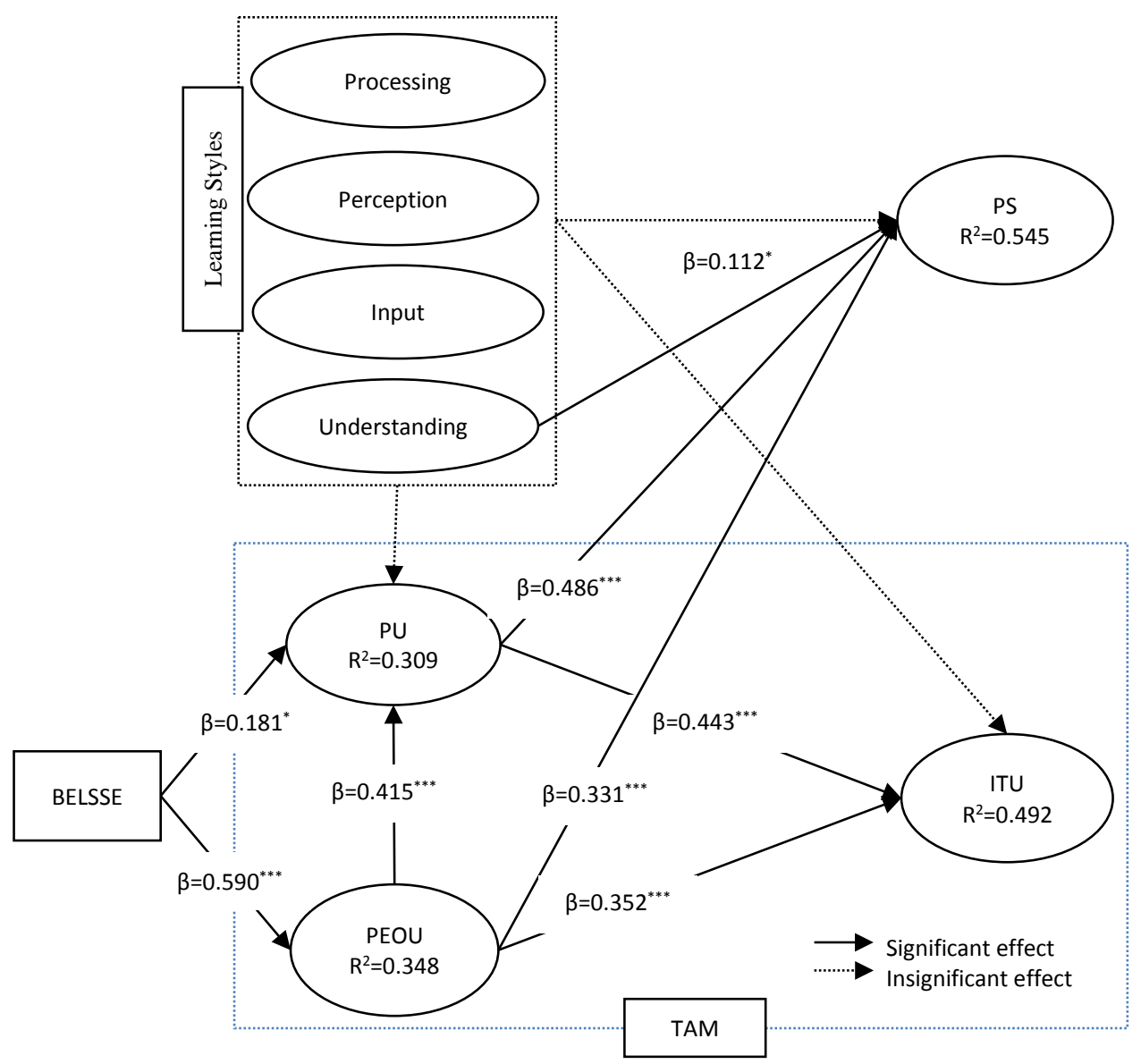

Figure 4. Results of the research framework

\section{Qualitative data}

To gain a wider understanding of learner perspectives, a qualitative approach was used. In a mixed method approach qualitative and quantitative data have to be integrated rather than keeping them separated. Researchers can initially report quantitative findings and follow this by qualitative themes that could either support or reject them (Creswell, Klassen, Clark, \& Smith, 2011). It is worth mentioning that all of the collected comments were in the Arabic, but the first author has translated them into the English language keeping the same meaning as mentioned by participants. A total of 48 students responded to the open-ended questions. Their perspectives were analysed by using the thematic approach. All comments were coded based on the identified themes. Generally, six advantages and one issue were highlighted by participants. Table 10 demonstrates the number and percentage of students who identified similar themes. It may be worth considering that some participants have reported more than one benefit or drawback of e-learning application. 
Table 10

The generated themes from the qualitative analysis

\begin{tabular}{|c|c|c|}
\hline \multicolumn{3}{|l|}{ BELS Advantages } \\
\hline Theme & Number & $\%$ \\
\hline A useful tool in teaching and learning & 15 & 31.25 \\
\hline Improving 'learner-teacher', 'learner-learner', and 'learner-content' interaction & 10 & 20.83 \\
\hline Providing alternative opportunities to understand a subject & 9 & 18.75 \\
\hline Expanding students' knowledge & 2 & 4.16 \\
\hline Saving learning time and effort & 2 & 4.16 \\
\hline Promoting intellectual abilities and individual skills of students & 2 & 4.16 \\
\hline \multicolumn{3}{|l|}{ The Issue Associated with BELS Application } \\
\hline Theme & Number & $\%$ \\
\hline The use of Moodle in online tests & 19 & 39.58 \\
\hline
\end{tabular}

\section{Discussion}

In this study, we extended TAM by incorporating learning styles as well as integrating technology acceptance and learner satisfaction in one model. The overall results did not support the influence of learning styles to contribute to the critique of this psychological education theory. However, the research advocated the use of TAM across cultural differences, revealed the influence of self-efficacy on PU and PEOU, and integrated satisfaction and behavioural intention in one model.

Our research model confirmed all of the hypotheses from the original TAM (Table 8). According to Venkatesh and Davis (2000), TAM typically accounts for $40 \%$ of the variance. The results from the present study exceeded the typical results of TAM to explain $49.1 \%$ of variance by assuming a direct effect between PEOU and ITU and without the mediation of ATU. Such findings support the appropriateness of TAM across-cultural differences. In accordance with other research, PU had the most direct and strongest effect on ITU in comparison to other factors (Davis et al., 1989; Park, 2009; Tarhini et al., 2015; Teo, 2008; Teo, 2009). This research is in agreement with such studies. Gefen and Straub (2000) explain the reason that underlies the weak effect of PEOU. They mentioned that this factor relates to task nature which assesses the intrinsic features of a technology, for example, flexibility, clarity, and ease of learning. PU, on the other hand, represents a response of users to assess a technology's extrinsic features such as outcome and technology assistance to achieve tasks. Accordingly, extrinsic features have a stronger influence on technology adoption. This can also be attributed to student experience or the nature of the learning technology. Tarhini et al. (2015) stated that the significance of PEOU is shown in the early stage of adoption, whereas it has a little to no effect on a population that is highly experienced in a particular technology.

Some of the prior literature has shown a correlation between gender differences and technology adoption. Gefen and Straub (1997) pointed out that PEOU and PU of men and women were affected by gender, but it did not influence ITU. In the study performed by Gefen and Straub (2000), women showed less interest, use, and adoption of educational computer tools than men. To some extent, Ong and Lai (2006) supported these outcomes. However, it was found that gender is a predictor of ITU as well. Tarhini et al. (2014), on the other hand, stated that gender did not moderate PU, PEOU, and ITU. Similarly, Vanderheyden and De Baets (2015) concluded that gender differences were neither correlated with learner performance nor satisfaction. Our analysis suggests that both men and women had a similar behavioural intention to use BELS and PS irrespective of their gender differences as pinpointed in Table 5. In Table 6, it is exhibited that there was a significant difference in both ITU and PS among the students in accordance with their study level. Post-hoc Tukey's HSD tests indicated that junior students had significantly lower ITU and PS than the other three groups at the 0.05 level of significance. This may be associated with other external variables such as its use in a non-interactive method for this group of students, whereas learners need to be highly motivated in order to accept such technologies in learning whether in a voluntarily or a non-voluntarily learning environment.

The learning style hypothesis was not confirmed in this research, which is consistent with other studies (Hong, 2002; Shaw, 2012). Learning style dimensions were not predictors for the dependent constructs (PU, PS, and ITU). Understanding dimension, on the other hand, was the only one that showed weak, but 
significant influence on PS. Furthermore, the outcomes suggest that learning style dimensions had a mild predictive ability on PU, PS, and ITU. Such findings are in agreement with the research performed by Brown et al. (2009). In their study, learning styles were also shown to have a limited influence on nine subscales of online learning environments. In this research, even though the examined learning environment adopted a one-size-fits-all approach, learners rated PS and ITU similarly irrespective of their individual styles as demonstrated in Table 5 . The only exception was for processing dimension. The $t$-test analysis exhibited that active learners were more likely to accept BELS and be satisfied. Based on FSLSM, active learners do not like to be passive participants in educational activities. They tend to discuss, brainstorm, question, and be involved practically. Giving these features, the LMS with its communication tools such as forum and wiki represents a suitable learning platform to serve their preferences. This outcome is compatible with the study conducted by Li (2015) where it was found that active learners possessed significantly higher intention towards an interactive learning technology (wiki) than the reflective group. Generally, the claim that there is no adequate evidence to justify incorporating learning styles could not be refuted.

Following ITU hypotheses, the study demonstrated that PU and PEOU were predictors of behavioural intention. This finding is in agreement with the assumption of TAM and supporting literature that states PU represents the best dominant determinant of ITU (Park, 2009; Shin \& Kang, 2015; Tarhini et al., 2015; Teo, 2009). It is also consistent with other studies that PEOU has a direct significant influence on ITU (Liu et al., 2010; Tarhini et al., 2014; Weng \& Tsai, 2015).

Pertaining to PS hypotheses, studies consistently indicated that PEOU and PU are important factors in predicting PS. Although both constructs predicted PS, PU indicated a larger effect than PEOU as in the prior research (Drennan, Kennedy, \& Pisarski, 2005; Sun et al., 2008; Weng \& Tsai, 2015). This highlights a rational link between these constructs, suggesting that the beliefs of learners in BELS usefulness have a crucial effect on their satisfaction. With regard to PEOU, learners may search for an alternative learning method if a particular learning technology requires a lot of effort to achieve a task and this, in turn, may affect their satisfaction.

BELSSE demonstrated a strong effect on PEOU and a mild significant impact on PU which means that this factor may affect PS and ITU indirectly. Furthermore, the effect of BELSSE on PEOU was larger than its influence on PU. One possible interpretation is that learners believe that blended e-learning is a useful learning technology regardless of their personal skills, but less experience in the use of a particular technology means the need for more effort to achieve a particular task. According to Ong and Lai (2006), self-efficacy had a greater impact on PEOU than PU. This finding was confirmed in this research. Additionally, Shin and Kang (2015) found that self-efficacy was a significant predictor of PEOU, whereas it did not influence PU. This is because less experienced students feel that they need greater effort to accomplish their tasks properly. Hence, educational institutions, particularly in developing countries, should provide a structured guideline and special training courses in order to improve student selfconfidence. As a consequence, our expectation is that Iraqi students need further training courses to encourage them using BELS as well as promoting their individual skills.

Qualitative data presented that in order to successfully implement BELS, some challenges need to be addressed. Most comments, however, revealed that the advantages outweighed the disadvantages to be compatible with the quantitative analysis. The main responses were grouped into two categories: benefits and issues as shown in Table 10.

On the pros side, $31.25 \%$ of them believed that e-learning is useful software that has the opportunity to improve learning and teaching in higher education. In addition, $20.83 \%$ of students found that the use of elearning alongside the physical classrooms has promoted the interaction with other peers, lecturers, and learning content. This outcome is in agreement with the conclusion of Emelyanova and Voronina (2014) that e-learning systems can promote the implementation of the social constructivist learning theory. Elearning can also provide an alternative approach to absorbing a topic. This advantage was identified by $18.75 \%$ of participants. Fewer students (4.16\%) stated that providing additional resources on the e-learning system can assist them to expand their knowledge. Others (4.16\%) found that its effective use can save time and effort. Similarly, $4.16 \%$ of respondents indicated that students can enhance their intellectual abilities by experiencing a new learning method such as via educational technology. These advantages were reflected by some of the students' comments below: 
Blended learning is very important where a topic is explained firstly in details in a classroom and all questions are discussed and answered. Then, in Moodle, the topic can be discussed again by using external information or ideas that may have a strong relationship to the topic.

... [BELS] keeps the interaction between students and subjects and it facilitates obtaining particular information when it is needed ...

The advantages are: students do not need to use social networks to get lectures and this, in turn, saves time, a topic can be discussed with a lecturer after reading it, the questions of students can assist the lecturer to identify weaknesses of students and, then, addressing them in a shortest time, and other students can benefit from these questions. In my opinion, there are no any disadvantages of this learning mode, on the other hand, it responds to the digital era ...

On the cons side, the inappropriate use of BELS in online tests can negatively affect student willingness to accept it. This issue was highlighted by $39.58 \%$ of participants. A possible reason is that some instructors might have a lack of experience in the use of BELS in online tests. Thus, conducting effective and diverse training programs can assist to address this issue. Moreover, other highlighted reasons by respondents were the limited type of questions in the web-based exams and the inconsistency between monthly and final exams since the latter is based on the paper-based approach. Therefore, students highly recommended the use of either online-based or paper-based tests. Examples of students' responses that reported this issue are:

It is a limited system and without a high benefit because [online-based] questions and tests are either true-false or multiple choices. In general, it is Okay, but it should be developed further to obtain more advantages... for me as a student, I visit the system once a week to download the lectures...

One test method should be followed either online-based or paper-based tests because of the difference in the style of questions between e-learning and traditional tests.

To sum up, although students faced some issues in the e-learning system, they believe that the benefits of blended learning far outweigh the drawbacks.

\section{Implications, recommendations, and limitations}

This study added a number of values in comparison to previous research. Firstly, TAM was rarely examined in Arabic populations and the soundness of the model across-cultures is significant to the research. Even though it is stated that Eastern and Western students differ in many aspects such as the social relationships, physical environment, autonomy, and learning styles (Chang et al., 2011), the present study exhibited that the original factors of TAM (PU and PEOU) can be used to determine technology acceptance regardless of such differences. Thus, it clearly contributes to the existing evidence about the robust construction of TAM. Secondly, identical factors were successfully used to predict adoption behaviour and perceived satisfaction. This means that both constructs can be integrated into one model instead of proposing separate models to explain each one. Finally, the psychological trait (learning styles) was extended to examine their implications on PU, PS, and ITU. Contrary to the theoretical assumption of educational psychologists (Felder \& Silverman, 1988), the results revealed that this trait had a limited predictive power on the research variables, and there was no significant difference between students' willingness to adopt e-learning and their satisfaction based on learning styles. Although the integration of learning styles theory did not positively influence the model, it empirically contributes to the existing critique regarding its impacts on education.

Based on the findings, the study has drawn four recommendations:

1. Accommodating hypermedia systems in accordance with learning styles are not recommended due to the weak correlation between learning styles, perceived satisfaction, and technology acceptance. This supports literature that pointed out learning styles did not influence academic performance as well (Al-Azawei, Al-Bermani, \& Lundqvist, 2016; Gomes \& Mendes, 2010; Prajapati, Dunne, Bartlett, \& Cubbidge, 2011); 
2. Educational institutions should consider other factors to enhance student satisfaction and behavioural intention towards LMS rather than exerting time and effort into integrating learning styles;

3. Training courses should be delivered to all learners in order to enhance their self-confidence and this, in turn, can positively influence learner beliefs and technology acceptance; and

4. Training sessions should also be provided for instructors in order to extend their knowledge about how e-learning can be effectively implemented.

In spite of the significant findings of this study, it suffers from many limitations which may be subject to further research. The first weakness is that the sample was from one college. Although it was sufficient to represent the population in higher education, recruiting samples from several universities and using random sampling approach can improve the generalisability of the findings. The other limitation is that the overall results of the proposed model may indicate a need for further research in order to integrate more variables. This may enhance the model's ability to predict perceived satisfaction and technology adoption.

\section{Conclusion}

Blended learning combines the advantages of traditional and online learning. It is widely applied to support F2F learning as well as responding to user needs. Investigating learner satisfaction and intention to use elearning alongside physical classrooms can predict whether learners will continue using this technology or not. Based on TAM, this study integrated perceived satisfaction and technology acceptance into one model. TAM was extended by incorporating other determinants, namely, learning styles and self-efficacy. The proposed model successfully identified the key factors that can explain learner satisfaction and BELS acceptance in the Middle East where few studies have investigated predictors of both factors in comparison to the West nations.

Gender differences did not show a significant association with any of the model's factors. Additionally, learning styles failed to predict PU, PS, and ITU. This finding added more to the existing debate regarding the absence of convincing evidence to advocate learning styles theory. As a result, it is recommended that learner needs should be considered from the start rather than accommodating EHSs according to learning styles. Moreover, our research supports the existing literature regarding the soundness of TAM constructs irrespective of cross-cultural differences.

\section{Acknowledgment}

The authors are grateful to the Iraqi Ministry of Higher Education and Scientific Research for supporting this study. They would also like to thank the anonymous reviewers for their valuable feedback that led to further improvement of the research.

\section{References}

Ahuja, M. K., \& Thatcher, J. B. (2005). Moving beyond intentions and toward the theory of trying: effects of work environment and gender on post-adoption information technology use. MIS Quarterly, 29(3), 427-459. http://dx.doi.org/10.1016/j.chb.2010.07.007

Ajzen, I. (1985). From intentions to actions: A theory of planned behavior. J. Kuhl, \& J. Beckmann (Eds.), In Action control: From cognition to behavior (pp. 11-39). New York: Springer Verlag. http://dx.doi.org/10.1007/978-3-642-69746-3_2

Ajzen, I. (1991). The theory of planned behavior. Organizational Behavior and Human Decision Processes, 50(2), 179-211. http://dx.doi.org/10.1016/0749-5978(91)90020-T

Ajzen, I., \& Fishbein, M. (1980). Understanding attitudes and predicting social behaviour. Englewood Cliffs, NJ: Prentice-Hall, Inc.

Akbulut, Y., \& Cardak, C. S. (2012). Adaptive educational hypermedia accommodating learning styles: A content analysis of publications from 2000 to 2011. Computers \& Education, 58(2), 835-842. http://dx.doi.org/10.1016/j.compedu.2011.10.008

Al-Azawei, A., Al-Bermani, A., \& Lundqvist, K. (2016). Evaluating the effect of Arabic engineering students' learning styles in blended programming courses. Journal of Information Technology Education: Research, 15, 109-130. Retrieved from 
http://www.informingscience.org/Publications/3423

Al-Azawei, A., \& Lundqvist, K. (2014). The impacts of learning styles, learning patterns and demographic factors on learners' performance in a blended learning environment. Proceedings of the I-Society (2014) Conference (pp. 105-111). London: IEEE.

Al-Din, A., \& AlRadhi, K. (2008). Distance learning e-Learning for Iraq: Concept and road map. American Society for Information Science and Technology, 34(3), 34-37.

Bagozzi, R. P. (2007). The legacy of the Technology Acceptance Model and a proposal for a paradigm shift. Journal of the Association for Information Systems, 8(4), 244-254.

Barrio-García, S., Arquero, J. L., \& Romero-Frías, E. (2015). Personal learning environments acceptance model : The role of need for cognition, e-learning satisfaction and students' perceptions. Educational Technology \& Society, 18(3), 129-141.

Benbasat, I., \& Barki, H. (2007). Quo vadis, TAM? Journal of the Association for Information Systems, 8(4), 211-218.

Bolliger, D. U., \& Wasilik, O. (2009). Factors influencing faculty satisfaction with online teaching and learning in higher education. Distance Education, 30(1), 103-116. http://dx.doi.org/10.1080/01587910902845949

Bouhnik, D., \& Marcus, T. (2006). Interaction in distance-learning courses. Journal of the American Society for Information Science and Technology, 57(3), 299-305. http://dx.doi.org/10.1002/asi.20277

Brown, E. (2007). The use of learning styles in adaptive hypermedia. Retrieved from http://etheses.nottingham.ac.uk/577/

Brown, T., Zoghi, M., Williams, B., Jaberzadeh, S., Roller, L., Palermo, C., \& Holt, T. A. (2009). Are learning style preferences of health science students predictive of their attitudes towards e-learning? Australasian Journal of Educational Technology, 25(4), 524-543.

Cagiltay, K., \& Bichelmeyer, B. (2000). Differences in learning styles in different cultures: A qualitative study. New Orleans, LA. Retrieved from http://files.eric.ed.gov/fulltext/ED445035.pdf.

Capece, G. \& Campisi, D., 2013. User satisfaction affecting the acceptance of an e-learning platform as a mean for the development of the human capital. Behaviour \& Information Technology, 32(4), 1-9.

Cha, H. J., Kim, Y. S., Park, S. H., Yoon, T. B., Jung, Y. M., \& Lee, J.-H. (2006). Learning style diagnosis based on user interface behavior for the customization of learning interfaces in an intelligent tutoring system. The 8th International Conference on Intelligent Tutoring Systems, Lecture Notes in Computer Science. Vol. 4053, 513-524. Berlin Heidelberg: Springer-Verlag. http://dx.doi.org/10.1007/11774303_51

Chang, L., Mak, M. C. K., Li, T., Wu, B. P., Chen, B. Bin, \& Lu, H. J. (2011). Cultural adaptations to environmental variability: An evolutionary account of east-west differences. Educational Psychology Review, 23(1), 99-129. http://dx.doi.org/10.1007/s10648-010-9149-0

Chin, W. W. (1998). Issues and opinion on structural equation modelling. MIS Quarterly, 22(1), 1. http://dx.doi.org/Editorial

Chiu, C. M., Hsu, M. H., Sun, S. Y., Lin, T. C., \& Sun, P. C. (2005). Usability, quality, value and elearning continuance decisions. Computers and Education, 45(4), 399-416. http://dx.doi.org/10.1016/j.compedu.2004.06.001

Coffield, F., Moseley, D., Hall, E., \& Ecclestone, K. (2004). Learning styles and pedagogy in post-16 learning: A systematic and critical review. Retrieved from http://sxills.nl/lerenlerennu/bronnen/Learning styles by Coffield e.a..pdf

Cohen, L., Manion, L., \& Keith, M. (2007). Research methods in education (6th ed.). London, UK: Routledge. Retrieved from http://journals.heacademy.ac.uk/doi/full/10.3108/beej.10.r1

Cook, D. A., \& Smith, A. J. (2006). Validity of index of learning styles scores: Multitrait-multimethod comparison with three cognitive/learning style instruments. Medical Education, 40(9), 900-907. http://dx.doi.org/10.1111/j.1365-2929.2006.02542.x

Creswell, J. W., Klassen, L. A. C., Clark, V. L. P., \& Smith, L. K. C. (2011). Best practices for mixed methods research in the health sciences. Office of Behavioral and Social Sciences Research National Institutes of Health. Retrieved from https://www.nursing.virginia.edu/media/Best_Practices_for_Mixed_Methods_Research.pdf

Dash, N. K. (2005). Module: Selection of the research paradigm and methodology. Retrieved from http://www.celt.mmu.ac.uk/researchmethods/Modules/Selection_of_methodology/

David, A. K. (2012). Multiple latent variable models: Confirmatory factor analysis. Retrieved from http://davidakenny.net/cm/mfactor.htm

Davis, F. (1986). A technology acceptance model for empirically testing new end-user information systems: Theory and results. (Doctoral thesis). Wayne State University, Detroit, Michigan. Retrieved 
from http://dspace.mit.edu/handle/1721.1/15192

Davis, F. D., Bagozzi, R., \& Warshaw, P. R. (1989). User acceptance of computer technology: A comparison of two theoretical models. Management Science, 35(8), 982-1003.

Dillman, D. A. (2007). Mail and internet surveys: The tailored design method (2nd ed.). Hoboken, NJ: John Wiley \& Sons.

Drennan, J., Kennedy, J., \& Pisarski, A. (2005). Factors affecting student attitudes toward flexible online learning in management education. The Journal of Educational Research, 98(6), 331-338.

Dunn, R., \& Dunn, K. (1974). Learning style as a criterion for placement in alternative programs. Phi Delta Kappan, 56(4), 275-278.

Dunn, R., Gemake, J., Jalali, F., Zenhausern, R., Quinn, P., \& Spiridakis, J. (1990). Cross-cultural differences in learning styles of elementary-age students from four ethnic backgrounds. Journal of Multicultural Counselling \& Development, 18(2), 68-93.

Dutton, J., Dutton, M., \& Perry, J. (2001). Do online students perform as well as lecture students? Journal of Engineering Education, 90(1), 131-136.

Edmunds, R., Thorpe, M., \& Conole, G. (2012). Student attitudes towards and use of ICT in course study, work and social activity: a technology acceptance model approach. British Journal of Educational Technology, 43(1), 71-84. http://dx.doi.org/10.1111/j.1467-8535.2010.01142.x

Emelyanova, N., \& Voronina, E. (2014). Introducing a learning management system at a Russian university: Students' and teachers' perceptions. The International Review of Research in Open and Distance Learning, 15(1), 272-289.

Felder, R. (1996). Matters of style. ASEE Prism, 6(4), 18-23.

Felder, R., \& Brent, R. (2005). Understanding student differences. Journal of Engineering Education, 94(1), 57-72. Retrieved from http://onlinelibrary.wiley.com/doi/10.1002/j.21689830.2005.tb00829.x/abstract

Felder, R., \& Silverman, L. (1988). Learning and teaching styles in engineering education. Engineering Education, 78(June), 674-681.

Felder, R., \& Soloman, B. A. (n.d.). Index of learning styles. Retrieved from http://www.engr.ncsu.edu/learningstyles/ilsweb.html

Felder, R., \& Spurlin, J. (2005). Applications, reliability and validity of the index of learning styles. International Journal of Engineering Education, 21(1), 103-112.

Fleming, N. D., \& Mills, C. (1992). Not another inventory, rather a catalyst for reflection. To Improve the Academy, 11(1), 137-155.

Fornell, C., \& Larcker, D. F. (1981). Evaluating structural equation models with unobservable variables and measurement error. Journal of Marketing Research, 18(1), 39-50. http://dx.doi.org/10.2307/3151312

Garrison, D. R., \& Kanuka, H. (2004a). Blended learning: Uncovering its transformative potential in higher education. Internet and Higher Education, 7(2), 95-105. http://dx.doi.org/10.1016/j.iheduc.2004.02.001

Gefen, D., \& Straub, D. W. (1997). Gender differences in the perception and use of e-mail: An extension to the technology acceptance model. MIS Quarterly, 21(4), 389-400. http://dx.doi.org/10.2307/249720

Gefen, D., \& Straub, D. W. (2000). The relative importance of perceived ease of use in IS adoption: A study of e-commerce adoption. Journal of the Association for Information Systems, 1(1), 1-28.

Gomes, A. J., \& Mendes, A. J. (2010). A study on student performance in first year CS courses. In Proceedings of the fifteenth annual conference on Innovation and technology in computer science education - ITiCSE '10 (pp. 113-117). Bilkent, Ankara, Turkey: ACM. http://dx.doi.org/10.1145/1822090.1822123

Graf, S. (2007). Adaptivity in learning management systems focussing on learning styles. (Doctoral dissertation). Athabasca University, Canada. Retrieved from http://citeseerx.ist.psu.edu/viewdoc/download?rep=rep1\&type=pdf\&doi=10.1.1.142.3221

Hair, J. F., Black, W. C., Babin, B. J., Anderson, R. E., \& Tatham, R. L. (2006). Multivariate data analysis (6th ed.). Upper Saddle River, NJ: Pearson Prentice Hall.

Hong, K.-S. (2002). Relationships between students' and instructional variables with satisfaction and learning from a Web-based course. The Internet and Higher Education, 5(3), 267-281. http://dx.doi.org/10.1016/S1096-7516(02)00105-7

Hong, W., Thong, James, Y. L., Wong, W.-M., \& Tam, K.-Y. (2001). Determinants of user acceptance of digital libraries: An empirical examination of individual differences and systems characteristics. Journal of Management Information Systems, 18(3), 97-124. 
http://dx.doi.org/10.1080/07421222.2002.11045692

Huang, Y. M. (2015). Exploring the factors that affect the intention to use collaborative technologies: The differing perspectives of sequential/global learners. Australasian Journal of Educational Technology, 31(3), 278-292.

Kolb, D. A. (1981). Experiential learning theory and the learning style inventory: A reply to Freedman and Stumpf. Academy of Management Review, 6(2), 289-296. http://dx.doi.org/10.5465/AMR.1981.4287844

Kolb, A. Y., \& Kolb, D. A. (2005). Learning styles and learning spaces: Enhancing experiential learning in higher education. Academy of Management Learning \& Education, 4(2), 193-212. http://dx.doi.org/10.5465/AMLE.2005.17268566

Lee, Y., Kozar, A. K., \& Larsen, K. R. T. (2003). The technology acceptance model: Past, present, and future. The Communications of the Association for Information Systems, 12(1), 752-780.

Legris, P., Ingham, J., \& Collerette, P. (2003). Why do people use information technology? A critical review of the technology acceptance model. Information \& Management, 40(3), 191-204. http://dx.doi.org/10.1016/S0378-7206(01)00143-4

Li, K. M. (2015). Learning styles and perceptions of student teachers of computer-supported collaborative learning strategy using wikis. Australasian Journal of Educational Technology, 31(1), 32-50.

Liaw, S.-S. (2008). Investigating students' perceived satisfaction, behavioral intention, and effectiveness of e-learning: A case study of the Blackboard system. Computers \& Education, 51(2), 864-873. http://dx.doi.org/10.1016/j.compedu.2007.09.005

Liu, I. F., Chen, M. C., Sun, Y. S., Wible, D., \& Kuo, C. H. (2010). Extending the TAM model to explore the factors that affect Intention to Use an Online Learning Community. Computers and Education, 54(2), 600-610. http://dx.doi.org/10.1016/j.compedu.2009.09.009

López-Pérez, M. V., Pérez-López, M. C., \& Rodríguez-Ariza, L. (2011). Blended learning in higher education: Students' perceptions and their relation to outcomes. Computers \& Education, 56(3), 818826. http://dx.doi.org/10.1016/j.compedu.2010.10.023

Mayer, R. E. (2011). Does styles research have useful implications for educational practice? Learning and Individual Differences, 21(3), 319-320. http://dx.doi.org/10.1016/j.lindif.2010.11.016

Moodle (2016). Moodle. Retrieved from https://moodle.net/sites/index.php?country=IQ

Ong, C. S., \& Lai, J. Y. (2006). Gender differences in perceptions and relationships among dominants of e-learning acceptance. Computers in Human Behavior, 22(5), 816-829. http://dx.doi.org/10.1016/j.chb.2004.03.006

Oxford, R. L., \& Anderson, N. J. (1995). A crosscultural view of learning styles. Language Teaching, 28(4), 201-215. http://dx.doi.org/10.1017/S0261444800000446

Pallant, J. (2013). SPSS survival manual: A step by step guide to data analysis using IBM SPSS (5th ed.). Maidenhead, UK: McGraw-Hill Education, Open University Press.

Park, S. Y. (2009). An analysis of the technology acceptance model in understanding university students' behavioral intention to use e-learning. Educational Technology \& Society, 12(2), 150-162. http://dx.doi.org/10.1007/s00340-009-3513-0

Pashler, H., McDaniel, M., Rohrer, D., \& Bjork, R. (2009). Learning styles: Concepts and evidence. Psychological Science in the Public Interest, 9(3), 105-119. http://dx.doi.org/10.1111/j.15396053.2009.01038.x

Peterson, E. R., Rayner, S. G., \& Armstrong, S. J. (2009). Researching the psychology of cognitive style and learning style: Is there really a future? Learning and Individual Differences, 19(4), 518-523. http://dx.doi.org/10.1016/j.lindif.2009.06.003

Popescu, E. (2010). Adaptation provisioning with respect to learning styles in a Web-based educational system: an experimental study. Journal of Computer Assisted Learning, 26(4), 243-257. http://dx.doi.org/10.1111/j.1365-2729.2010.00364.x

Prajapati, B., Dunne, M., Bartlett, H., \& Cubbidge, R. (2011). The influence of learning styles, enrolment status and gender on academic performance of optometry undergraduates. Ophthalmic and Physiological Optics, 31(1), 69-78. http://dx.doi.org/10.1111/j.1475-1313.2010.00798.x

Runeson, P., \& Höst, M. (2009). Guidelines for conducting and reporting case study research in software engineering. Empirical Software Engineering, 14(2), 131-164. http://dx.doi.org/10.1007/s10664-0089102-8

Shaw, R. S. (2012). A study of the relationships among learning styles, participation types, and performance in programming language learning supported by online forums. Computers and Education, 58(1), 111-120. http://dx.doi.org/10.1016/j.compedu.2011.08.013

Shin, W. S., \& Kang, M. (2015). The use of a mobile learning management system at an online university 
and its effect on learning satisfaction and achievement. International Review of Research in Open and Distributed Learning, 16(3), 110-130.

Srite, M., \& Karahanna, E. (2006). The role of espoused in technology values in technology acceptance. MIS Quarterly, 30(3), 679-704.

Straub, D. W., \& Burton-Jones, A. (2007). Veni, vidi, vici: Breaking the TAM logjam. Journal of the Association for Information Systems, 8(4), 223-229.

Šumak, B., Heric `ko, M., \& Pušnik, M. (2011). A meta-analysis of e-learning technology acceptance: The role of user types and e-learning technology types. Computers in Human Behavior, 27(6), 2067-2077. http://dx.doi.org/10.1016/j.chb.2011.08.005

Sun, P.-C., Tsai, R. J., Finger, G., Chen, Y.-Y., \& Yeh, D. (2008). What drives a successful e-Learning? An empirical investigation of the critical factors influencing learner satisfaction. Computers \& Education, 50(4), 1183-1202. http://dx.doi.org/10.1016/j.compedu.2006.11.007

Szajna, B. (1996). Empirical evaluation of the revised technology acceptance model. Management Science, 42(1), 85-92.Tarhini, A., Hassouna, M., \& Abbasi, M. S. (2015). Towards the acceptance of RSS to support learning: An empirical study to validate the technology acceptance model in Lebanon. Electronic Journal of E-Learning, 13(1), 30-41.

Tarhini, A., Hone, K., \& Liu, X. (2014). Measuring the moderating effect of gender and age on e-learning acceptance in England: A structural equation modeling approach for an extended technology acceptance model. Educational Computing Research, 51(2), 163-184.

Tarus, J. K., Gichoya, D., \& Muumbo, A. (2015). Challenges of implementing e-learning in Kenya : A case of Kenyan public universities. International Review of Research in Open and Distributed Learning, 16(1), 120-141.

Taylor, S., \& Todd, P. A. (1995). Understanding information technology usage: A test of competing models. Information Systems Research, 6(2), 144-176. http://dx.doi.org/10.1287/isre.6.2.144

Teng, K. E. (2015). An analysis of ODL student perception and adoption behavior using the technology acceptance model. International Review of Research in Open and Distributed Learning, 15(6), 275288.

Teo, T. (2008). Assessing the computer attitudes of students: An Asian perspective. Computers in Human Behavior, 24(4), 1634-1642. http://dx.doi.org/10.1016/j.chb.2007.06.004

Teo, T. (2009). Modelling technology acceptance in education: A study of pre-service teachers. Computers and Education, 52(2), 302-312. http://dx.doi.org/10.1016/j.compedu.2008.08.006Tobias, R. D. (1995). An introduction to partial least squares regression. Paper presented at the 20th Proc. Ann. SAS Users Group Int. Conf., Orlando, Florida. Retrieved from http://support.sas.com/techsup/technote/ts509.pdf

Vanderheyden, K., \& De Baets, S. (2015). Does cognitive style diversity affect performance in dyadic student teams? Learning and Individual Differences, 38, 143-150. http://dx.doi.org/10.1016/j.lindif.2015.01.006

Van Zwanenberg, N., Wilkinson, L. J., \& Anderson, A. (2000). Felder and Silverman's index of learning styles and Honey and Mumford's learning styles questionnaire: How do they compare and do they predict academic performance? Educational Psychology, 20(3), 365-380. http://dx.doi.org/10.1080/713663743

Venkatesh, V., \& Bala, H. (2008). Technology acceptance model 3 and a research agenda on interventions. Decision Sciences, 39(2), 273-315. http://dx.doi.org/10.1111/j.1540-5915.2008.00192.x

Venkatesh, V., \& Davis, F. D. (1996). A model of the antecedents of perceived ease of use: Development and test. Decision Sciences, 27(3), 451-481. http://dx.doi.org/10.1111/j.1540-5915.1996.tb01822.x

Venkatesh, V., \& Davis. F. D. (2000). A theoretical extension of the technology acceptance model: Four longitudinal field studies. Management Science, 46(2), 186-204. http://dx.doi.org/10.1287/mnsc.46.2.186.11926

Venkatesh, V., Morris, M. G., Davis, G. B., \& Davis, F. D. (2003). User acceptance of information technology: Toward a unified view. MIS Quarterly, 27(3), 425-478. http://dx.doi.org/10.2307/30036540

Weng, C., \& Tsai, C. (2015). Social support as a neglected e-learning motivator affecting trainee's decisions of continuous intentions of usage. Australasian Journal of Educational Technology, 31(2), 177-192.

Wixom, B. H., \& Todd, P. a. (2005). A theoretical integration of user satisfaction and technology acceptance. Information Systems Research, 16(1), 85-102. http://dx.doi.org/10.1287/isre.1050.0042

Wu, J.-H., Tennyson, R. D., \& Hsia, T.-L. (2010). A study of student satisfaction in a blended e-learning system environment. Computers \& Education, 55(1), 155-164. 
http://dx.doi.org/10.1016/j.compedu.2009.12.012

Zywno, M. (2003). A contribution to validation of score meaning for Felder-Soloman's index of learning styles. In Proceedings of the 2003 American Society for Engineering Education Annual Conference \& Exposition, Washington, USA, 1-16.

Corresponding author: Ahmed Al-Azawei, a.al-azawei@pgr.reading.ac.uk

Australasian Journal of Educational Technology @ 2017.

Please cite as: Al-Azawei, A., Parslow, P., \& Lundqvist, K. (2017). Investigating the effect of learning styles in a blended e-learning system: An extension of the technology acceptance model (TAM). Australasian Journal of Educational Technology, 33(2), 1-23. https://doi.org/10.14742/ajet.2758 


\section{Appendix A The research instrument blended learning (BL)}

\begin{tabular}{|c|c|c|}
\hline Item & Question & Reference \\
\hline \multicolumn{3}{|c|}{$\begin{array}{l}\text { Intention to Use (ITU) } \\
\text { (IT) }\end{array}$} \\
\hline ITU1 & Assuming I have access to e-learning (Moodle) in BL, I intend to use it. & Adapted from \\
\hline ITU2 & $\begin{array}{l}\text { Given that I have access to e-learning (Moodle), in BL, I predict that I } \\
\text { would use it. }\end{array}$ & $\begin{array}{l}\text { Venkatesh \& } \\
\text { Davis (2000) }\end{array}$ \\
\hline \multicolumn{3}{|c|}{ Perceived Usefulness (PU) } \\
\hline PU1 & Using e-learning (Moodle) improves my performance in BL. & Adapted from \\
\hline PU2 & Using e-learning (Moodle) in BL increases my scientific performance. & Venkatesh \& \\
\hline PU3 & Using e-learning (Moodle) in BL enhances my learning effectiveness. & Davis (2000) \\
\hline \multicolumn{3}{|c|}{ Perceived Ease of Use (PEOU) } \\
\hline PEOU1 & The interaction with e-learning (Moodle) is clear and understandable. & Adapted from \\
\hline PEOU2 & $\begin{array}{l}\text { Interacting with e-learning (Moodle) in BL does not require a lot of } \\
\text { mental effort. }\end{array}$ & $\begin{array}{l}\text { Venkatesh \& } \\
\text { Davis (2000) }\end{array}$ \\
\hline PEOU3 & I find e-learning (Moodle) to be easy to use in BL. & \\
\hline PEOU4 & I find the environment of e-learning (Moodle) to be easy to use. & \\
\hline \multicolumn{3}{|c|}{ Blended E-Learning System Self-Efficacy (BELSSE) } \\
\hline BELSSE1 & $\begin{array}{l}\text { I can use e-learning (Moodle) in BL, if there is no one around to tell me } \\
\text { what to do as I go. }\end{array}$ & $\begin{array}{l}\text { Adapted from } \\
\text { Wu et al. }\end{array}$ \\
\hline BELSSE2 & $\begin{array}{l}\text { I can use e-learning (Moodle) in BL, if I had never used a system like it } \\
\text { before. }\end{array}$ & $(2010)$ \\
\hline BELSSE3 & $\begin{array}{l}\text { I can use e-learning (Moodle) in BL, even if there is no assistant } \\
\text { illustration tool with the system. }\end{array}$ & \\
\hline \multicolumn{3}{|c|}{ Perceived Satisfaction (PS) } \\
\hline PS1 & I am satisfied with the BELS efficiency. & Adapted from \\
\hline PS2 & I am satisfied with the BELS effectiveness. & Chiu et al. \\
\hline PS3 & Overall, I am satisfied with the BELS. & (2005) \\
\hline
\end{tabular}


Appendix B

Factor analysis

\begin{tabular}{|c|c|c|c|c|c|c|c|}
\hline & & & & & Factors & & \\
\hline $\begin{array}{l}\text { Latent } \\
\text { Factor }\end{array}$ & Item & $\begin{array}{c}\text { Factor loading (> } \\
\text { 0.7) }\end{array}$ & 1 & 2 & 3 & 4 & 5 \\
\hline \multirow[t]{2}{*}{$\overline{\text { ITU }}$} & ITU1 & 0.917 & .360 & & .733 & & \\
\hline & ITU2 & 0.922 & & & .816 & & \\
\hline \multirow[t]{3}{*}{ PU } & PU1 & 0.848 & & & .565 & .610 & \\
\hline & PU2 & 0.798 & & & & .719 & \\
\hline & PU3 & 0.864 & .424 & & & .698 & \\
\hline \multirow[t]{4}{*}{ PEOU } & PEOU1 & 0.755 & & & & & .644 \\
\hline & PEOU2 & 0.654 & & & & & .854 \\
\hline & PEOU3 & 0.853 & .510 & & .326 & & .471 \\
\hline & PEOU4 & 0.803 & .341 & .404 & .438 & & .457 \\
\hline \multirow[t]{3}{*}{ BELSSE } & BELSSE1 & 0.847 & & .725 & & & .310 \\
\hline & BELSSE2 & 0.823 & & .781 & & & \\
\hline & BELSSE3 & 0.839 & & .827 & & & \\
\hline \multirow[t]{4}{*}{ PS } & PS1 & 0.906 & .852 & & & & \\
\hline & PS2 & 0.907 & .797 & & & & \\
\hline & PS3 & 0.858 & .710 & & & .318 & \\
\hline & Variance \% & & 18.979 & 15.834 & 14.505 & 12.471 & 12.191 \\
\hline
\end{tabular}

Notes. Rotation converged in 8 iterations. Loading less than 0.3 was excluded. 